in the neighbourhood of Hordie huge masses of fallen cliff alter. nate with hollow chines. At Barton also the loss is great, averaging over certain periods one yard per annum, and the whole frontage of Christchurch Bay is similarly affected.

The shingle immediately westward of Hurst becomes smaller, as is universally the case with these spits. Hurst Beach in effect, with alternating withdrawals and renewals, due to change of wind, represents by its height and the size of its pebbles the general leeward accumulating drift.

General observation leads to the conclusion that littoral shingle travels mainly along the shore, as in all cases the coarse pebbles are succeeded by fine shingle, and this ultimately, by sand, sili, or clay; but that spits of shingle grow out into deep water, creating a base for themselves the numerous nesses on our coasts amply show; but before arriving on the shore that shingle does travel at very considerable depths is shown by such cases as the a! ove-mentioned submarine shingle bank west of the Needles passage and the "Boulders" off Selsea Bill.

Here the "Park Anchorage" eastward of the Bill is the traditional site of the bishop's see, and hydrograpnic authorities cited in the English Channel Pilot describe the gravel bottom as rough and thinly covering a strong clay.

6, Queen Anne's Gate, Westminster, S.W., May i8

\section{Difficult Cases of Mimicry}

IN the very interesting communication by $\mathrm{Mr}$. Wallace, in NATURE, ante p. 86, on some difficult cases of mimicry, there is one statement which apparently challenges comment.

Mr. Wallace states that although it has been so suggested, it is highly improbable that young birds bave a hereditary instinct enabling them to distinguish uneatable butterflies antecedent to experience. Mr. Wallace has not alluded to the very thorough and careful experiments made by the late Mr. Dougl. A. Spalding on this point. It is unnecessary to refer to the results obtained by Mr. Spalding in proving the inherited acquisition of ideas and experience in young chickens, it will at least suffice to repeat the observations made by him, on the actions of a young turkey which he had adopted-" When chirping within the uncracked shell." Now this young turkey, not only on the tenth day of its life, exhibited the most in'tense terror at the sound of a hawk's voice which was confined in a cupboard but also proved its inherited knowledge of uneatable insects.

"When a week old my turkey came on a bee right in its path - the first, I believe, it had ever seen. It gave the danger chirp, stood for a few seconds with outstretched neck and marked expression of fear, then turned off in another direction. On this hint I made a vast number of experiments with chickens and bees. In the great majority of instances the chickens gave evidence of instinctive fear of these sting-bearing insects, but the results were not uniform, and perhaps the most accurate general statement I can give is, that they were uncertain, shy and suspicious."

If domesticated fowls and turkeys exhibit such inherited " instinct," may we not postulate a much greater exccss of the same in purely insectivorons birds in a state of nature. And if this is so, it will be unnecessary to explain away, what appears to be one of the most philosophical considerations in the doctrine of "mimicry."

W. L. Distant

\section{Deaf-Mutes}

J'APprends seulement aujourd'hui par M. Graham Bell que La Nature ̀̀ bien voulu mentionner mes communications à l'Académie des Sciences sur l'accent des sourds muets. Je regrette que les Comptes Rendus n'aient pas reproduit mes communications in extenso et que M. le Secrétaire perpétuel se soit borné à en faire une analyse incompléte. Je prends donc la liberté de vous adresser ces quelques lignes afin que vos lecteurs sachent au juste la portée de ma communication.

J'ai dit que nous sommes frappés de la ressemblance des visages et quelquefois aussi des mains parce que se sont les seules parties du corps, qui ne soient pas couvertes par les vêtements, mais qu'évidemment la ressemblance s'etend à toutes les parties du corps. J'ajoute même que la ressemblance ne s'arrête pas aux traits extérieurs, on doit la retrouver entre les organes. Pourquoi les organes de la voix feraieat-ils seuls exception à la règle générale?

M. le sénateur Robin et M. Milne-Edwards, de I'Institut, à qui on ne saurait refuser la compétence en ces matières, nous disaient qu'il ne comprenaient pas qu'on pût faire des objections sérieuses au fait que j'ai signalé touchant la transmission hériditaire de l'accent; que la voix, avec ses diverses propriétés, hauteur, in. tensité, timbre, accent, est une manifestation des organes-vocaux au même titre que toutes les manifestations dont notre corps est le siége. Rien ne se produit au dehors qui n'ait sa cause ou son siége au dedans; c'est dans la constitution intime de notre corps qu'il faut chercher la raison de tous les phénomènes externes. Ainsi s'expliquent les transmissions par voie d'hérédité, soit des aptitudes comme celles pour les mathématiques, les arts graphiques, etc. ; soit des affections maladives comme la goutte, le cancer, la folie, etc. ; soit des monstruosités comme les doigts surnuméraires, le bec-de lièvre, etc. Pourquoi dans les ressemblances, les organes vocaux seraient-ils exceptés?

Il faut chercher la ressemblance dans la cellule ; sans doute, il n'est pas facile de la saisir, mais nous n'osons pas dire, que c'est chose impossible. Une longue expérience est nécessaire pour arriver à saiser des nuances imperceptibles au grand nombre. $\mathrm{Ne}$ sait-on-pas qu'un berger reconnait et distingue chaque mouton de son troupeau, tandis que pour nous tous les moutons sont les mêmes à fort peu près.

Ne serait-il pas possible, d'ailleurs, qu'il y eut moins de nuances d'accent chez les sourds-muets et les entendants-parlants americains que chez les Français du Nord et du Midi, de l'Est et de l'Ouest. La voix de nos chers Alsaciens est teintée de sons germaniques, tandis que celle de nos Provençaux a acquis une sonorité et un timbre particuliers qui lui viennent sans doute du long séjour des Romains dans le Midi. Peut-être nous est-il plus facile de constater ces nuances dans la voix chez les sourdsmuets de notre pays.

Voici un nouveau fait très curieux sur lequel j'appelle votre attention.

Nanterre (Seine)

Felix Hement

\section{Caution to Solar Observers}

IN the interest of solar observers I send you a caution. A first-class sample of black glass was set with a bit of white paper behind it, and exposed for an instant to the focus of a 7 -inch lens. The paper was charred where an eye would be placed. A longer exposure of a few seconds made the glass burst asunder.

Niddry Lodge, Kensington, London, W. J. F. Campbell

\section{Aurora Borealis}

WHAT was, probably, the termination of the aurora seen at Worcester and Dublin on May 14 was observed here, by me, between midnight and I a.m. of the morning of the I8th. At that time, and for some time after, I saw along the northwest horizon a strong, green, auroral glow. The evening of the I 4 th was bitterly cold; the sunset clouds threatened snow, wind, light north-north-east light, cloudy. At dawn, the sky was cloudless and wonderfully clear. 'The 15 th was warm and pleasant.
Glasgow, May 24
S. Maitland Baird Glennill

\section{ON THE MUTUAL RELATIONS OF CARBON} AND IRON IN STEEL ${ }^{ \pm}$

$\mathrm{IN}$ this paper the author sets himself to prove the following four propositions concerning steel: (I) the carbon of steel is (primarily) in a state of simple absorption in the iron; (2) the hardening of steel is due to a metamorphic change in the condition of the carbon, which then assumes a crystalline form closely analogous to the diameter ; (3) the varying temper of steel results from the dissociation of this crystalline carbon, at varying but low temperatures; (4) the real strength of steel does not vary to any material degree with a varying content of carbon-that is, ceteris paribus, steel is not increased in tensile strength by an increased percentage of carbon.

With regard to No. I, the author rejects the idea that carbon in steel can be in chemical combination. The only possible hypothesis would be that it is found as a carbide of iron dissolved in excess of iron ; and this no modern author holds." It may be alleged in its support that hydrocarbon gas is evolved on dissolving steel in hydrochloric acid; but the great variation in the results and the fact that more or less carbon is at the same time deposited, forbid us to suppose that we have here a definite chemical decomposition. The Eggerty colour test, again, which was supposed to be founded on the same theory, has been in great measure abandoned on account of its inaccuracy. The

${ }^{1}$ Abstract of paper by Mr. George Woodcock, read_before the Iron and Steel Institute. 